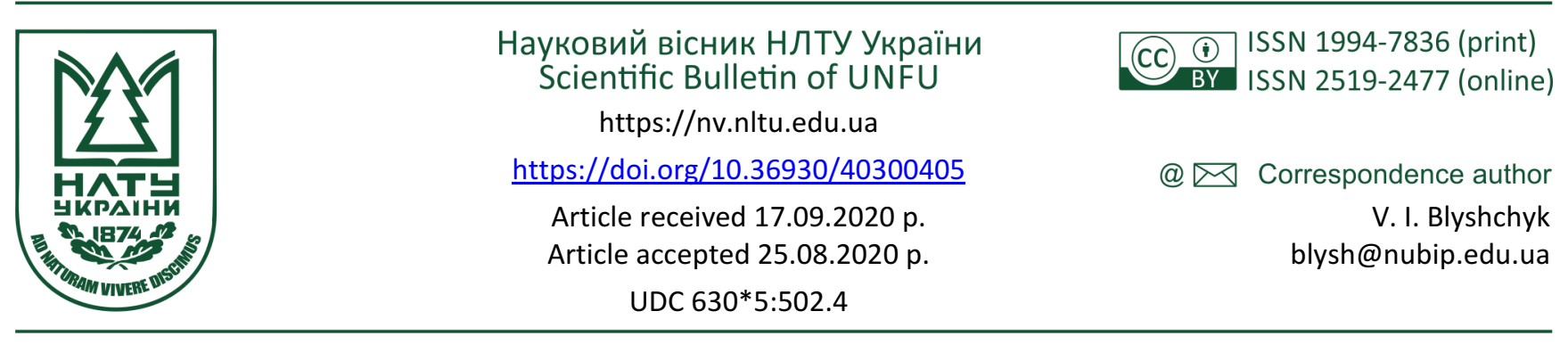

О. С. Гоцик', Г. А. Сахарук², В. І. Блищик', П. І. Лакида',

${ }^{1}$ Національний університет біоресурсів і природокористування Украйни, м. Киӥв, Украӥна ${ }^{2}$ Шацький лісовий коледж ім. В. В. Сулька, смт. Шаџьк, Украӥна

\title{
ІНФОРМАЦЙНЕ ЗАБЕЗПЕЧЕННЯ ПРОЦЕСУ МОДЕЛЮВАННЯ БІОПРОДУКТИВНОСТІ ЛІСІВ ЧЕРЕМСЬКОГО ПРИРОДНОГО ЗАПОВІДНИКА
}

\begin{abstract}
Важливим етапом у процесі дослідження біопродуктивності лісів є агрегування дослідних даних про наявні для конкретного регіону тимчасові пробні площі (ТПП), які відображали б основні таксаційні показники та найпоширеніші типи лісорослинних умов деревостанів головних лісотвірних видів. Для дослідження фітомаси дерев і деревостанів використано методи лісової таксації: суцільного переліку та вибіркові. Пробні площі закладали за методикою П. І. Лакиди. Для інформативного забезпечення оцінювання біопродуктивності та екологічного потенціалу лісостанів Черемського природного заповідника застосовано 64 тимчасові пробні площі, з яких 44 закладено в деревостанах природного походження і 20 - у штучних насадженнях. Причому 2 ТПП заклав безпосередньо аспірант та 62 ТПП взято з фонду кафедри таксації лісу та лісового менеджменту Національного університету біоресурсів і природокористування України. Тимчасові пробні площі проаналізовано за деревними видами, походженням, типами лісорослинних умов, класами бонітету, відносними повнотами та групами віку. Використані ТПП адекватно описують найпоширеніші соснові, вільхові і березові деревостани головних лісотвірних порід заповідника і характеризують наявний стан лісів досліджуваного об'єкта. Деякі таксаційні показники (середній вік, діаметр і висот $a$ ) аналізували на наявність в масиві даних випадаючих спостережень та екстремальних значень. Діаграми розмаху основних таксаційних показників вільхи клейкої показують, що у зібраних дослідних даних вони відсутні, а вибірка охоплює широкий діапазон спостережень. У масиві даних березових насаджень присутні "викиди" у розподілі за середніми віком і діаметром. Діаграми розмаху середніх таксаційних показників деревостанів сосни звичайної побудовано окремо для природного і штучного походження. Зібраний експериментальний матеріал є репрезентативним, що дає змогу на його основі розробити математичні моделі компонентів фітомаси модальних деревостанів та оцінити їхню динаміку.
\end{abstract}

Ключові слова: тимчасова пробна площа; тип лісорослинних умов; діаметр; висота; клас бонітету; діаграма розмаху.

\section{Вступ}

Наука, як і будь-який інший вид людської діяльності, передбачає використання певних способів і прийомів для досягнення зазначеної мети. Кожне наукове дослідження супроводжується вивченням конкретного об'єкта, предмета чи явища $з$ метою розкриття закономірностей його виникнення, розвитку і перетворення в інтересах суспільства [3]. Складність і багатогранність будь-якої наукової проблеми вимагає певної методики дослідження. Сучасна наука володіє потужним арсеналом різних методів досліджень, призначених для розв'язання різноманітних наукових завдань [6].

Кліматичні зміни і забруднення навколишнього середовища підривають стабільність природних екосистем і негативно впливають на життя людини. Запаси фітомаси і первинної продукції є важливими показниками, що характеризують біопродуктивність лісів, а також їхню здатність регулювати газообмін атмосфери i глобальний цикл вуглецю. Управління вуглецевим балансом лісових фітоценозів як у межах країни, так і на регіональному рівні можливе за наявності репрезентативної інформаційної бази екосистемних функцій лісів.

Доволі новітніми та перспективними є дослідження біопродуктивності насаджень у заповідних територіях для збереження унікального біорізноманіття цих об'єктів, вирішення екологічних проблем і розв'язання завдань регіональних біологічних й енергетичних програм [12]. Зважаючи на те, що Черемський природний заповідник було створено 19 грудня 2001 р., дослідженню його лісових екосистем присвячено небагато наукових робіт, але водночас екосистемні послуги лісів інших об'єктів природо-заповідного фонду вже тривалий час оцінюють дослідники.

Об'єкт дослідження - процеси формування біопродуктивності деревостанів.

Предмет дослідження - методи ы засови визначення біопродуктивності деревостанів Черемського при-

\section{Інформація про авторів:}

Гоцик Ольга Степанівна, аспірант, кафедра таксації лісу та лісового менеджменту. Email: gotsyk89@gmail.com

Сахарук Галина Антонівна, канд. с.-г. наук, голова циклової комісії лісівничих дисциплін. Email: galina_sakharuk@ukr.net

Блищик Володимир Іванович, канд. с.-г. наук, ст. викладач, кафедра таксації лісу та лісового менеджменту. Email: blysh@nubip.edu.ua; https://orcid.org/0000-0002-5440-3142

Лакида Петро Іванович, д-р с.-г. наук, професор, директор Навчально-наукового інституту лісового і садово-паркового господарства. Email: lakyda@nubip.edu.ua; https://orcid.org/0000-0003-3639-2969

Цитування за ДСту: Гоцик О. С., Сахарук Г. А., Блищик В. І., Лакида П. І. Інформаційне забезпечення процесу моделювання біопродуктивності лісів Черемського природного заповідника. Науковий вісник НЛтУ України. 2020, т. 30, № 4. С. 30-36.

Citation APA: Hotsyk, O. S., Sakharuk, H. A., Blyshchyk, V. I., \& Lakyda, P. I. (2020). Information database for modeling of bioproductivity of forests in Sheremsky Nature Reserve. Scientific Bulletin of UNFU, 30(4), 30-36. https://doi.org/10.36930/40300405 
родного заповідника.

Мета дослідження: проаналізувати основні таксаційні показники, які впливають на процеси формування біопродуктивності лісостанів Черемського природного заповідника.

Для досягнення зазначеної мети поставлено такі основні завдання дослідження: агрегувати і проаналізувати дослідні дані з оцінювання біопродуктивності лісів заповідника; встановити відповідність цих даних таксаційній та типологічній характеристиці насаджень; виявити в масиві даних випадаючі спостереження i екстремальні значення за допомогою діаграми розмаху.

Наукова новизна отриманих результатів дослідження полягає в тому, що вперше сформовано базу даних тимчасових пробних площ 3 оцінювання біопродуктивності деревостанів Черемського природного заповідника і визначено відповідність дослідних даних наявному стану лісів досліджуваного об'єкта.

Практична значущість результатів дослідження полягає у підтвердженні статистичними методами того, що їх можна використати під час розроблення системи математичних моделей для оцінювання обсягів фітомаси та депонованого в ній вуглецю сосновими, вільховими та березовими деревостанами заповідника.

Аналіз останніх досліджсень та публікацій. На сьогодні в Україні отримано результати обсягів фітомаси, депонованого в ній вуглецю та киснепродуктивності лісів багатьох заповідних об'єктів. Зокрема, перші дослідження біопродуктивності об'єктів природно-заповідного фонду здійснила Г. С. Домашовець [9]. Ними стали ННП "Сколівські Бескиди" (акумульовано близько 2,87 млн т вуглецю у 5,77 млн т фітомаси) і НПП "Яворівський" (містить 0,55 млн т фітомаси) у Львівській області.

Пізніше Г. А. Сахарук визначив загальні обсяги фітомаси та депонованого в ній вуглецю у лісових насадженнях Шацького національного природного парку [11]. Встановлено, що протягом досліджуваного періоду (24 роки) середня щільність фітомаси у насадженнях зазначеного НПП поступово зростає у всіх групах лісотвірних порід, а отримані результати підтверджують важливість цього природно-заповідного об'єкта у покращенні стану повітряного басейну регіону (загальна киснепродуктивність становить близько 41 тис. т на рік).

Бокоч В. В. зі співавторами [13] досліджували структуру фітомаси лісів Карпатського національного природного парку у межах функціональних зон парку. За їхніми даними деревостани Карпатського НПП є досить надійним джерелом поглинання вуглецю та продукування кисню (щорічно депонують 177 тис. т вуглецю), а найбільшою продуктивністю характеризуються лісові насадження зони регульованої рекреації.

Мельник О. М. виконав повидільне оцінювання біопродуктивності лісів Національного природного парку "Прип'ять-Стохід", яке показало, що найбільші обсяги фітомаси накопичені у хвойних і м'яколистяних насадженнях (понад $90 \%$ ) [18]. Дослідник наголошує, що ефективне використання ресурсного потенціалу лісових насаджень цього парку сприятиме вирішенню екологічних проблем регіону.

Останні дослідження щодо оцінювання дослідних даних біопродуктивності лісів стосувалися таких об'єктів природно-заповідного фонду чи регіонів із значним анторопогеним навантаженням, як Вижницький [22] і Голосіївський НПП [1], Державної організації "Резиденція "Залісся" $[14,15]$, а також лісів Лісостепової Придніпровської Височини [4] і Південного Придніпровського Полісся [5].

Матеріали та методи дослідження. Для дослідження фітомаси та продукції дерев і деревостанів використали методи лісової таксації: суцільного переліку та вибіркові. Під час виконання польових робіт та лабораторно-камерального опрацювання дослідних даних за основу використано методику П. І. Лакиди [8].

Для інформаційного забезпечення оцінки біотичної продуктивності та екологічного потенціалу лісостанів Черемського природного заповідника використано 64 тимчасові пробні площі (ТПП), з яких 44 закладено в деревостанах природного походження і 20 - у штучних насадженнях. Більшість ТПП (62 шт.) використано 3 наукового фонду кафедри таксації лісу та лісового менеджменту Національного університету біоресурсів і природокористування України [12, 15]. Тимчасові пробні площі закладено у типових умовах місцезростання і повністю описують деревостани головних лісотвірних порід заповідника та прилеглих до нього лісових масивів. Кількість ТПП за головними деревними видами та походженням показано в табл. 1.

Табл. 1. Розподіл кількості ТПП за деревними видами та походженням

\begin{tabular}{|c|c|c|c|}
\hline \multirow{2}{*}{ Порода } & \multicolumn{3}{|c|}{ Кількість пробних площ у деревостанах, шт. } \\
\cline { 2 - 4 } & природних & штучних & усього \\
\hline Сосна & 20 & 19 & 39 \\
\hline Вільха & 13 & 1 & 14 \\
\hline Береза & 11 & - & 11 \\
\hline Разом & $\mathbf{4 4}$ & $\mathbf{2 0}$ & $\mathbf{6 4}$ \\
\hline
\end{tabular}

Відомо, що ріст і продуктивність деревостанів залежить від лісорослинних умов. Так, у гірших умовах місцезростання дерева одного деревного виду ростуть повільніше і мають меншу продуктивність порівняно $з$ деревами однакового віку, які зростають у кращих лісорослинних умовах [19]. Домінуючу частку площ у Черемському природному заповіднику становлять субори (68 \%), серед яких найпоширеніші вологі субори. Понад третину становлять сирі (18\%) та мокрі (15\%) субори. Також тут трапляються сирі сугруди (12\%), які є досить родючими та сприятливими для росту вільхи клейкої високої продуктивності, i, безумовно, характерні для Полісся бори $\left(\mathrm{A}_{1}-\mathrm{A}_{5}-18 \%\right)$ [10]. Тому ТПП було підібрано і закладено саме в таких умовах (табл. 2).

Як відомо, від лісорослинних умов напряму залежить і продуктивність лісів, показником якої слугує бонітет лісу (лат. bonitas - добротність). Визначають за середньою висотою дерев домінуючої породи насаджень у певному віці. Розрізняють 5 і більше класів бонітету. До класу належать найпродуктивніші насадження, які, порівняно 3 іншими того самого віку, дають найбільший приріст деревини; до $\mathrm{V}$ - найменш продуктивні. Для насаджень, продуктивність яких вища за I клас чи нижча за V клас, застосовують індексні позначення: $\mathrm{I}^{\mathrm{a}}, \mathrm{I}^{\mathrm{b}}, \mathrm{I}^{\mathrm{c}}, \mathrm{I}^{\mathrm{d}}, \mathrm{I}^{\mathrm{e}}, \mathrm{I}^{\mathrm{f}}$ та $\mathrm{V}^{\mathrm{a}}, \mathrm{V}^{\mathrm{b}}$. Бонітет лісу залежить від грунту, клімату та інших умов, які необхідно враховувати у плануванні заходів підвищення продуктивності деревостану.

Оскільки у Черемському природному заповіднику трапляються різноманітні типи лісорослинних умов (А, 
$\mathrm{B}, \mathrm{C})$, то й деревостани тут ростуть за різним класами бонітету. Загалом у заповіднику переважають насадження II (30,9 \%) та III (26,6 \%) класів бонітету [10]. То- му й більшість ТПП (33 шт.) закладено в деревостанах такої продуктивності (табл. 3).

Табл. 2. Розподіл кількості ТПП за породами, походженням та типами лісорослинних умов (перше число - природні деревостани, друге - штучні)

\begin{tabular}{|c|c|c|c|c|c|c|c|c|c|c|c|}
\hline \multirow{2}{*}{ Порода } & \multicolumn{10}{|c|}{ ТЛУ, природні/штучні, шт. } & \multirow{2}{*}{ Усього } \\
\hline & $\mathrm{A}_{2}$ & $\mathrm{~A}_{3}$ & $\mathrm{~A}_{4}$ & $\mathrm{~B}_{2}$ & $\mathrm{~B}_{3}$ & $\mathrm{~B}_{4}$ & $\mathrm{~B}_{5}$ & $\mathrm{C}_{3}$ & $\mathrm{C}_{4}$ & $\mathrm{C}_{5}$ & \\
\hline Сосна & $2 / 8$ & $3 /-$ & $2 /-$ & $4 / 10$ & $8 / 1$ & & $1 /-$ & & & & $20 / 19$ \\
\hline Вільха & & & & & & & & $1 /-$ & $8 / 1$ & $4 /-$ & $13 / 1$ \\
\hline Береза & & & & $5 /-$ & $3 /-$ & $1 /-$ & & $1 /-$ & $1 /-$ & & $11 /-$ \\
\hline Разом & $2 / 8$ & $3 /-$ & $2 /-$ & $9 / 10$ & $11 / 1$ & $1 /-$ & $1 /-$ & $2 /-$ & $9 / 1$ & 4/- & $44 / 20$ \\
\hline
\end{tabular}

Табл. 3. Розподіл кількості ТПП за породами, походженням та класами бонітету

\begin{tabular}{|c|c|c|c|c|c|c|c|}
\hline \multirow{2}{*}{ Порода } & \multicolumn{6}{|c|}{ Клас бонітету, природні/штучні, шт. } & \multirow{2}{*}{ Усього } \\
\hline & $\mathrm{I}^{\mathrm{a}}$ & I & II & III & IV & $\mathrm{V}$ & \\
\hline Сосна & $4 / 1$ & $5 / 6$ & $7 / 7$ & $2 / 4$ & $2 / 1$ & $-1-$ & $20 / 19$ \\
\hline Вільха & $2 /-$ & $3 /-$ & $5 / 1$ & $3 /-$ & $-1-$ & $-1-$ & $13 / 1$ \\
\hline Береза & $1 /-$ & $5 /-$ & $5 /-$ & $-1-$ & $-1-$ & $-1-$ & $11 /-$ \\
\hline Разом & $7 / 1$ & $13 / 6$ & $17 / 8$ & $5 / 4$ & $2 / 1$ & $-1-$ & $44 / 20$ \\
\hline
\end{tabular}

Табл. 4. Розподіл кількості ТПП за породами, походженням та відносними повнотами

\begin{tabular}{|c|c|c|c|c|c|c|c|c|c|}
\hline \multirow{2}{*}{ Порода } & \multicolumn{7}{|c|}{ Відносна повнота, природні/штучі, шт. } & \multirow{2}{*}{ Усього } \\
\cline { 2 - 10 } & 0,3 & 0,4 & 0,5 & 0,6 & 0,7 & 0,8 & 0,9 & 1,0 і > & $2 / 1$ \\
\hline Сосна & $-/ 1$ & $-/ 3$ & $2 / 1$ & $2 / 2$ & $5 / 3$ & $4 / 2$ & $3 / 3$ & $4 / 4$ & $20 / 19$ \\
\hline Вільха & $-/-$ & $1 /-$ & $-/-$ & $1 /-$ & $3 /-$ & $1 / 1$ & $4 /-$ & $3 /-$ & $13 / 1$ \\
\hline Береза & $2 /-$ & $3 /-$ & $1 /-$ & $3 /-$ & $1 /-$ & $-/-$ & $-/-$ & $1 /-$ & $11 /-$ \\
\hline Разом & $\mathbf{2 / 1}$ & $\mathbf{4 / 3}$ & $\mathbf{3 / 1}$ & $\mathbf{6 / 2}$ & $\mathbf{9 / 3}$ & $\mathbf{5 / 3}$ & $\mathbf{7 / 3}$ & $\mathbf{8 / 4}$ & $\mathbf{4 4 / 2 0}$ \\
\hline
\end{tabular}

Табл. 5. Розподіл кількості ТПП за породами, походженням та групами віку

\begin{tabular}{|c|c|c|c|c|c|}
\hline \multirow{2}{*}{ Порода } & \multicolumn{3}{|c|}{ Табл. Г. Розподіл кількості ТПП за породами, походженням та групами віку } & \multirow{2}{*}{ Усього } \\
\cline { 2 - 6 } & Молодняки & Середньовікові & Приглі & $20 / 19$ \\
\hline Сосна & $4 / 16$ & $9 / 1$ & $3 / 1$ & $-/-$ & $13 / 1$ \\
\hline Вільха & $2 /-$ & $5 / 1$ & $6 /-$ & $1 /-$ & $11 /-$ \\
\hline Береза & $1 /-$ & $5 /-$ & $4 /-$ & $\mathbf{5 / 1}$ & $\mathbf{4 4 / 2 0}$ \\
\hline Разом & $\mathbf{7 / 1 6}$ & $\mathbf{1 9 / 2}$ & $\mathbf{1 3 / 1}$ & & \\
\hline
\end{tabular}

Однією з таксаційних характеристик деревостану, що характеризує їх продуктивність, є повнота - показник щільності стояння стовбурів на одиниці площі. Розрізняють абсолютну і відносну повноту. За відносною повнотою насадження поділяють на: високоповнотні $(0,8-1,0)$, середньоповнотні $(0,7-0,5)$, низькоповнотні $(0,4-0,3)$, рідколісся $(0,2-0,1)$ і поодинокі дерева (до 0,1 )

У Черемському природному заповіднику трапляються різні за повнотою деревостани. Більшість 3 них $(73,9 \%)$ мають повноту 0,6-0,8. Низько- та високоповнотні насадження трапляються рідко [10]. Для об'єктивнішої характеристики лісів цього об'єкта досліджень ТПП підібрано в деревостанах з максимальним діапазоном повнот: від 0,3 до 1,0 (табл. 4).

Важливою ознакою, яка впливає на біопродукційні процеси у лісовому фітоценозі, $є$ його вік. Розподіл кількості тимчасових пробних площ за групами віку подано в табл. 5.

У Черемському ПЗ серед усіх лісотвірних порід домінують середньовікові насадження, участь яких становить 72,9 \% від площі вкритих лісовою рослинністю лісових ділянок, а запас - 78,5 \% від загального запасу лісів заповідника. Молодняки та стиглі насадження становлять незначну частку. Повністю відсутні перестиглі насадження [10]. Тому ТПП закладені в насадженнях усіх вікових груп, окрім перестійних, і переважно в середньовікових деревостанах.

\section{Результати дослідження та їх обговорення}

Загальна площа вкритих лісовою рослинністю лісових ділянок Черемського природного заповідника стано- вить 1664,0 га, загальний запас насаджень - 289,6 тис. м². Лісова рослинність займає $55,9 \%$ сучасної території резервату, причому переважну роль у формуванні лісового намету відіграють хвойні деревостани $(75,4 \%$ від загального запасу лісового фонду). М'яколистяні насадження у структурі лісового фонду за запасом становлять тільки 23,0\%, твердолистяні практично відсутні $(1,6 \%)$. Сосна звичайна займає панівне місце і зростає на площі 1085,7 га, що становить 65,2 \% вкритих лісовою рослинністю лісових ділянок. Відповідно і запас іiі найбільший - 215,09 тис. м³, або 74,3\% від загального запасу деревостанів заповідника [15].

Під час моделювання біопродуктивності лісів важливо, щоб таксаційні показники набували ознак нормального розподілу (розподілу Гауса або "дзвоноподібного" (bell-shaped curve)) або дуже близьких до нього [20]. Цей розподіл найчастіше застосовують для аналізу даних під час дослідження природних явищ. Не менш важливо встановити випадаючі спостереження ("викиди") або екстремальні значення в експериментальній вибірці, які можуть істотно впливати на результати моделювання.

Для цієї мети використаємо діаграму розмаху (коробковий графік або графік "ящик з вусами" (англ. ВохAnd-Whisker Plot, Box Plot)), яка дає змогу візуалізувати статистичні характеристики вибірки через їх квартилі [17]. На рис. 1-3 наведено розподіл спостережень основних таксаційних показників ТПП (середніх віку, діаметра та висоти) у межах деревних видів.

Верхню і нижню сторони "коробки" на діаграмах розмаху визначають третій $\left(Q_{3}\right)$ та перший $\left(Q_{1}\right)$ квартилі, лінія всередині "коробки" - це медіана (другий квар- 
тиль $\left.\left(Q_{2}\right)\right)$, а лінії поза межами третього та першого квартилів дорівнюють максимальному та мінімальному значенні вибірки (не враховуючи "викидів"). Випадаючі значення (outliers) розподілу позначені суцільно зафарбованими точками $(\bullet)$, а екстремальні значення - зірочками $(*)[16]$.

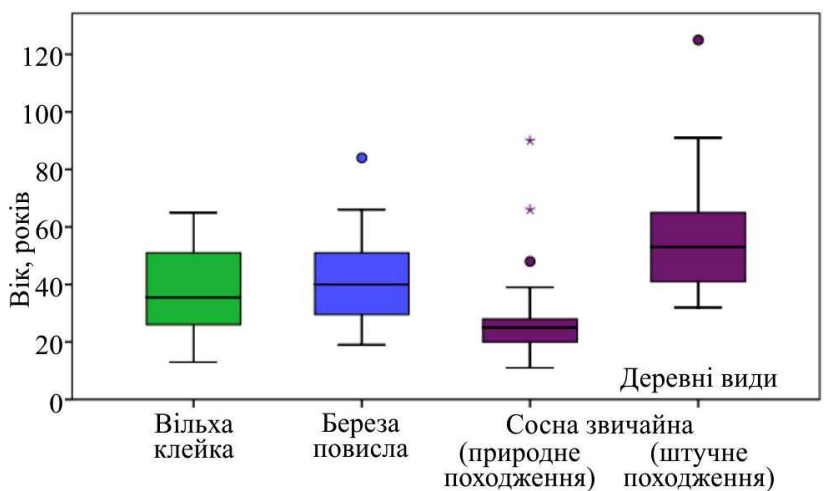

Рис. 1. Діаграма розмаху середнього віку насаджень, у яких закладені ТПП, за деревними видами та за походженням

Квартилі - це значення, які ділять ряд розподілу даних на чотири рівні частини. Вони є корисним інструментом виміру розкиду, оскільки менш залежні від екстремальних значень чи перекосу в даних порівняно iз стандартним відхиленням. Водночас, медіана ділить певний набір дослідних даних навпіл [20].

Усі зазначені показники дають змогу грунтовно проаналізувати певний розподіл даних. Перевага такого підходу в тому, що немає серед них однієї найважливішої статистики, а всі є однаково інформативними і дозволяють встановити центральну тенденцію (медіана), розмах (квартилі), величину мінливості (мінімальне та максимальне значення) і нетипові чи екстремальні значення.

Діаграми розмаху основних таксаційних показників вільхи клейкої показують, що у зібраних дослідних даних відсутні випадаючі значення, а вибірка охоплює широкий діапазон спостережень у кожному із аналізованих показників.

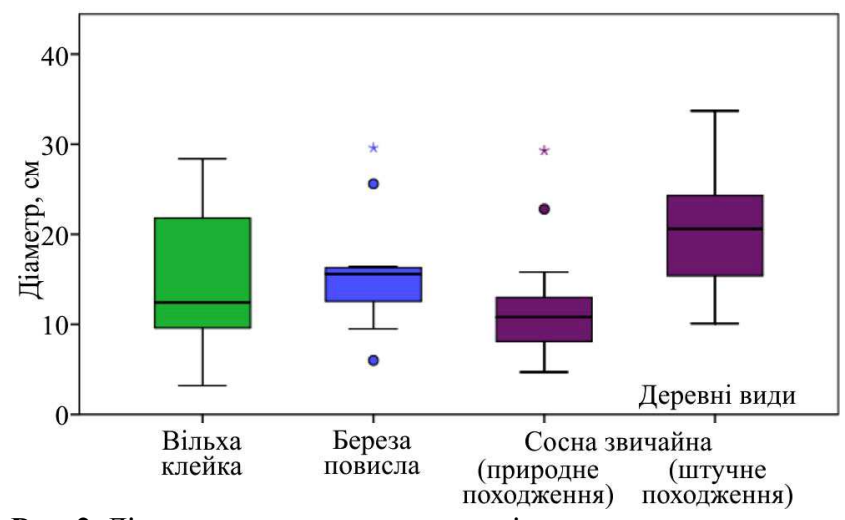

Pис. 2. Діаграма розмаху середнього діаметра насаджень, у яких закладені ТПП, за деревними видами та за походженням

У масиві даних березових насаджень присутні "викиди" у розподілі за середніми віком і діаметром. Водночас, закладені ТПП характеризуються малим розмахом середнього діаметра, тобто наявні випадаючі й екстремальні значення матимуть значний вплив на результати моделювання. Зважаючи на це важливо детальніше проаналізувати таксаційні показники цих 3 ТПП для унеможливлення зміщених оцінок фітомаси.
Діаграми розмаху середніх таксаційних показників деревостанів сосни звичайної побудовані окремо для природного і штучного походження. 3 рис. 1-3 видно, що зібрані дослідні дані відрізняються за всіма показниками: насадження природного походження характеризуються нижчими значеннями. Вибірка соснових насаджень природного походження має значно менший розмах і більше "викидів". Тому експериментальні дані цієї деревної породи потребують подальшого аналізу на доцільність їх поділу за походженням, шляхом порівняння основних таксаційних показників на значущість різниці їх середніх чи дисперсій за певними статистичними критеріями.

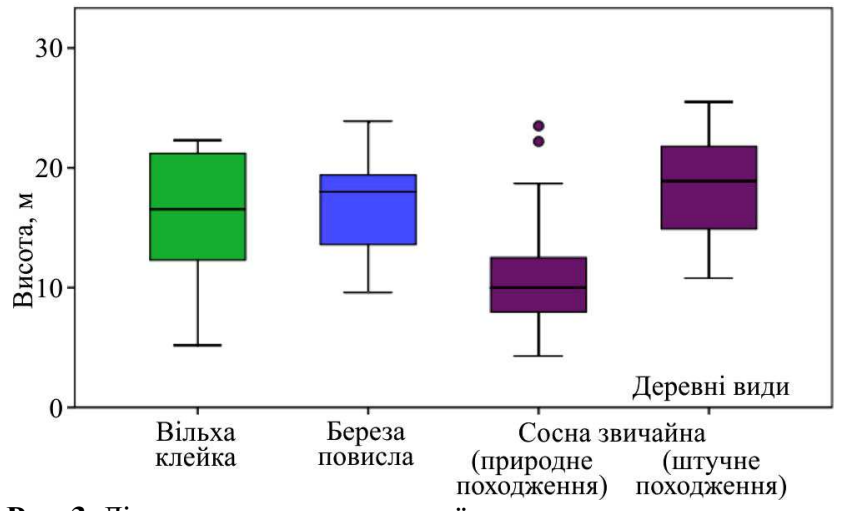

Рис. 3. Діаграма розмаху середньої висоти насаджень, у яких закладені ТПП, за деревними видами та за походженням

Важливою таксаційною ознакою є запас, який є основою для розрахунку конверсійних коефіцієнтів - показників, які конвертують запас у живу біомасу i iї складові [21]. На рис. 4 подано розподіл запасу вільхових, березових і соснових насаджень, у яких закладені ТПП, з віком.

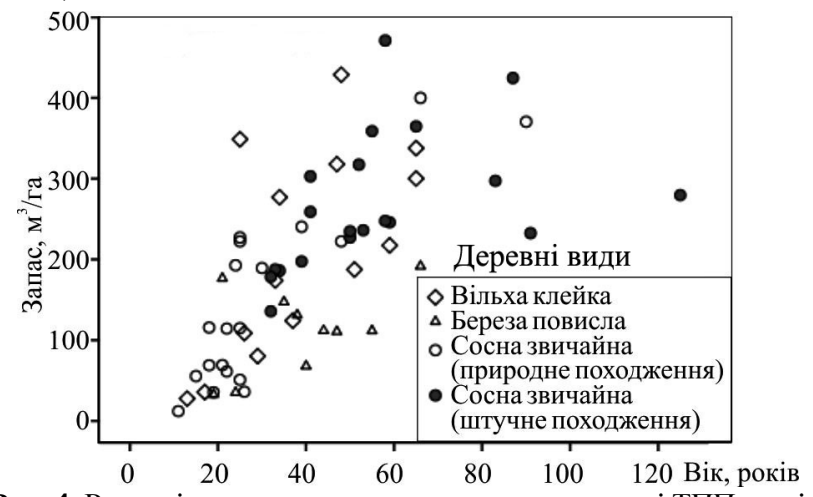

Рис. 4. Розподіл запасу насаджень, у яких закладені ТПП, за віком і деревними видами та за походженням

Графічне подання розподілу запасу за віком підтверджує попередні висновки про обмеженість дослідних даних для моделювання біопродуктивності соснових насаджень окремо за їх походженням (відсутні ТПП закладені у штучних насадженням до 30-річного віку і природних - після 50-річного, не враховуючи екстремальних значень).

\section{Висновки}

Для збирання експериментальних даних використано комплексну методику П. І. Лакиди, яка передбачає виконання польових лісотаксаційних робіт.

У процесі проведення досліджень використано експериментальні дані 64 тимчасових пробних площ регіону (частину 3 яких закладено на території об'єкта ПЗФ) з банку науково-дослідних даних кафедри такса- 
ції лісу та лісового менеджменту Національного університету біоресурсів і природокористування України. У насадженнях природного походження закладено 44 ТПП, штучного - 20 ТПП.

Дослідні дані деревостанів сосни звичайної природного і штучного походження відрізняються за всіма таксаційними показниками. При цьому насадження природного походження характеризуються нижчими значеннями i їх вибірка має значно менший розмах i більше "викидів". Тому експериментальні дані цієї деревної породи потребують подальшого аналізу перед їх використанням для процесу моделювання.

Діаграми розмаху основних таксаційних показників вільхи клейкої показують, що у зібраних дослідних даних вони відсутні, а вибірка охоплює широкий діапазон спостережень. У масиві даних березових насаджень присутні "викиди" у розподілі за середніми віком і діаметром.

Значення біометричних показників деревостанів, в яких закладені тимчасові пробні площі, близькі до модальних насаджень Черемського природного заповідника. А зібраний експериментальний матеріал дає підстави зробити висновок про приналежність деревостанів, в яких опрацьовувалися ТПП, до статистично близьких рядів, що дає змогу використовувати його для дослідження взаємозв'язків між таксаційними параметрами і величини їх впливу на процеси накопичення фітомаси деревостанами природного заповідника за компонентами.

\section{References}

1. Dubrovets, B. V. (2016). Experimental base of empirical data for the bioproductivity assessment of National Natural Park "Holosiivskyi". Scientific Bulletin of NULES of Ukraine, 255, 46-53. [In Ukrainian].

2. Hensiruk, S. A. (2007). Ukrainian Encyclopedia of Forestry. (Vol. 2). Lviv: NVF "Ukrainski Tekhnolohii". [In Ukrainian].

3. Hryshchenko, I. M., Hryhorenko, O. M., \& Boryseiko, V. O. (2001). Basics of science research. Kyiv: Kyiv National University of Trade and Economics. [In Ukrainian].

4. Kovalevskyi, S. S. (2015). The influence of forests on the stabilization and improvement of Bila Tserkva Environment. Scientific Bulletin of UNFU, 25(4), 40-44. [In Ukrainian].

5. Kovalska, S. S. (2016). Experimental database of the research of pine stands artificial biomass of South Pridneprovsky Polissya. Scientific Bulletin of UNFU, 26(1), 93-97. https://doi.org/10.15421/40260112

6. Krushelnytska, O. V. (2003). Research Methodology and Organization. Kyiv: Kondor. [In Ukrainian].

7. Lakyda, M. O., \& Vasylyshyn, R. D. (2016). Modeling of biological productivity of pine forest stands of the State organization "Residence Zalessy". Scientific Basis for Increasing the Productivity and Biological Sustainability of Forest and Urban
Ecosystems: 66th Scientific and Technical Conference of Faculty Members, Researchers, Doctoral Students and Postgraduate Students based on the results of scientific activity in 2015. Lviv: Abstracts of the report, 66-68. [In Ukrainian].

8. Lakyda, P. I. (2002). Phytomass of forests of Ukraine. Ternopil: Zbruch. [In Ukrainian].

9. Lakyda, P. I., \& Domashovets, H. S. (2009). Bioproductivity of the forests of Lviv region and its dynamics. Korsun-Shevchenkivskyi: FOP Havryshenko, V. M. [In Ukrainian].

10. Lakyda, P. I., \& Hotsyk, O. S. (2019). Structure, species composition and productivity of forests of Sheremsky nature reserve. Scientific Bulletin of UNFU, 29(3), 9-12. https://doi.org/10.15421/40290301

11. Lakyda, P. I., \& Sakharuk, H. A. (2013). Bioproductivity of forests of Shatsky National Park. Korsun-Shevchenkivskyi: FOP Havryshenko, V. M. [In Ukrainian].

12. Lakyda, P. I., Blyshchyk, V. I., \& Blyshchyk, I. V. (2017). Primary Production of black alder forests of Ukrainian Polissya. Korsun-Shevchenkivskyi: FOP Havryshenko, V. M. [In Ukrainian].

13. Lakyda, P. I., Bokoch, V. V., \& Vasylyshyn, R. D. (2015). Bioproductivity of forest phytocoenoses of the Carpathian National Nature Park. Korsun-Shevchenkivskyi: FOP Havryshenko, V. M. [In Ukrainian].

14. Lakyda, P. I., Vasylyshyn, R. D., Blyshchyk, V. I., Bilous, A. M., Matushevych, L. M., Lashchenko, A. H., ... Dubrovets, B. V. (2017). Broadleaved forests of Ukraine: live biomass and experimental data. Korsun-Shevchenkivskyi: FOP Havryshenko, V. M. [In Ukrainian].

15. Lakyda, P. I., Vasylyshyn, R. D., Blyshchyk, V. I., Lakyda, I. P., Terentiev, A. Yu., Domashovets, H. S., ... Stratii, N. V. (2018). Experimental data on live biomass of Ukrainian coniferous forests. Kyiv: "PC Komprynt" LLC.

16. Landau, S., \& Everitt, B. S. (2004). A handbook of statistical analyses using SPSS. Boca Raton: Chapman\& Hall/CRC/.

17. McGill, R., Tukey, J. W., \& Larsen, W. A. (1978). Variations of Box Plots. The American Statistician, 32(1), 12-16. https://doi.org/10.2307/2683468

18. Melnyk, O. M. (2015). Experimental database of the research of forests of National Natural Park "Prypiat-Stokhid". Scientific Bulletin of NULES of Ukraine, 25(1), 30-36. [In Ukrainian].

19. Myroniuk, V. V., Svynchuk, V. A., Bilous, A. M., \& Vasylyshyn, R. D. (2019). Forest mensuration. Kyiv: NULES of Ukraine. [In Ukrainian].

20. Nikitin, K. E., \& Shvidenko, A. Z. (1978). Methods and techniques for processing forest information. Moscow: Forestry industry. [In Russian].

21. Schepaschenko, D., Moltchanova, E., Shvidenko, A., Blyshchyk, V., Dmitriev, E., Martynenko, O., ... Kraxner, F. (2018). Improved estimates of biomass expansion factors for Russian forests. Forests, 9(6), 312-316. https://doi.org/10.3390/19060312

22. Stratij, N. V. (2016). Experimental database of forests of the National Natural Park "Vyzhnitskyi". Scientific Bulletin of UNFU, 26(7), 157-162. https://doi.org/10.15421/40260725

O. S. Hotsyk', H. A. Sakharuk', V. I. Blyshchyk', P. I. Lakyda'

${ }^{I}$ National University of Life and Environmental Sciences of Ukraine, Kyiv, Ukraine

${ }^{2}$ Shatsk Forest College named after V. V. Sulka, Shatsk, Ukraine

\section{INFORMATION DATABASE FOR MODELING OF BIOPRODUCTIVITY OF FORESTS}

IN CHEREMSKY NATURE RESERVE

Research data aggregation on temporary sample plots (TSPs) available for the region is an important stage in the study of forest bioproductivity. TSPs should reflect the main biometric indices and the most typical growth conditions of the main forest-forming species stands. The methods of forest mensuration were used to study live biomass of trees and stands. Sample plots were established in accordance with the methodology proposed by P.I. Lakyda. Sixty four temporary sample plots were used as an information database for estimation of bioproductivity and ecological potential of Cheremsky Nature Reserve. Of these, 44 TSPs were established in natural origin stands and 20 - in artificial stands. Moreover, 2 TSPs were established directly by a postgraduate student and 62 TSPs were taken from the fund of the Department of Forest Mensuration and Forest Management of the National University of Life and 
Environmental Sciences of Ukraine. Temporary sample plots were analyzed by tree species, origin, forest growth conditions, site index, relative stocking, and age groups. TSPs adequately describe the most common pine, alder and birch stands of the main forestforming species of the reserve and characterize existing state of forests of the studied object. Particular biometric indices such as mean age, diameter and height were analyzed to identify potential outliers and extreme values in the dataset. Box plots of the major biometric indices of alder stands show that outliers are absent in collected experimental data and the sample covers a wide range of observations. The dataset of birch stands contains outliers in distribution by average age and diameter. Box plots of mean biometric indices of pine stands are constructed separately for natural and artificial origin. The collected experimental data is representative and allows developing mathematical models of live biomass components of modal stands and estimating its dynamics.

Keywords: temporary sample plot; forest growth conditions; diameter; height; site index; box plots. 